\title{
Whose culture? Fanzines, politics and agency
}

Book or Report Section

Accepted Version

Worley, M. (2018) Whose culture? Fanzines, politics and agency. In: Ripped, Torn and Cut: Pop, Politics and Punk Fanzines from 1976. Manchester University Press, Manchester, pp. 55-71. ISBN 9781526120595 Available at http://centaur.reading.ac.uk/81421/

It is advisable to refer to the publisher's version if you intend to cite from the work. See Guidance on citing.

Publisher: Manchester University Press

All outputs in CentAUR are protected by Intellectual Property Rights law, including copyright law. Copyright and IPR is retained by the creators or other copyright holders. Terms and conditions for use of this material are defined in the End User Agreement. 


\section{CentAUR}

Central Archive at the University of Reading

Reading's research outputs online 


\section{Whose culture? Fanzines, politics and agency}

\section{Matthew Worley}

The impetus for starting a (punk) fanzine was often clear enough. Writing in the first issue of Sniffin' Glue (1976), Mark Perry bemoaned the weekly music press' failure to understand 'this thing called "punk rock"'. 'The weeklys [sic] are so far away from the kids that they can't possibly say anything of importance', he complained: 'why don't they stick to Queen and all that trash that drive around in expensive cars' ${ }^{1}$ For Tony Drayton, communicating from the edge of Glasgow in November 1976, Ripped \& Torn afforded him 'the only way to read my views on the punk scene'. ${ }^{2}$ Steve Burke, meanwhile, told Granada TV's Brass Tacks (1977) that he began making Shy Talk to get involved. 'I'm tone deaf', he explained, 'but I wanted to be part of [Manchester punk] so I started a fanzine up'. ${ }^{3}$

Less apparent, perhaps, were the repercussions of such impulse: the effect to the cause. Beyond giving expression to the youthful enthusiasms engendered by pop music and revealing a healthy disdain for commercial media - how did fanzines contribute to the initiatives filtered through punk? In Sniffin' Glue's case, Perry's eight pages of fervent text served as a catalyst; a stimulus for countless other homemade magazines to flower in London and across the country. ${ }^{4}$ Simultaneously, Sniffin' Glue and the 'zines it inspired affirmed the DIY-ethos associated with punk, embodying a cut ' $n$ ' paste aesthetic that signified qualities of immediacy, dissonance and irreverence. ${ }^{5}$ For Perry, as for Drayton and Burke, writing a fanzine enabled access to an emergent culture through which to trace, celebrate and shape its development. While Perry formed a band (Alternative TV) and 
became a go-to person amidst the media clamor of 1976-77, Drayton navigated punk's trajectory through eighteen issues of Ripped \& Torn and, from 1980, six issues of Kill Your Pet Puppy, intervening into subcultural debate and defending punk's potential from deviations both real and imagined. Born of the grass-roots, fanzines covered local and provincial scenes to forge networks and lend support. Shy Talk 'builds up everything that's going on around Manchester', Denise Lloyd (a fellow young punk from the city) stated at the time. ${ }^{6}$

As this suggests, punk's fanzines opened up a cultural space. Not only did they allow for creative and political expression, but they also enabled a means of intervention. Most importantly, perhaps, they offered a site to claim, contest and retain a sense of cultural ownership in the face of media distortion or wider disinterest. The three 'zines considered here - JOLT, Anathema and Hard As Nails - each, in their different ways, sought to inform and (re)direct the cultures of which they formed part. They voiced opinion and contributed to a conversation. Beneath any prevailing cultural narrative, be it defined in newsprint or captured on film to be replayed over-and-over as disembodied spectacle, lay alternate interpretations scribbled, typed and held together with glue and staples. In fanzines we find cultures recorded from the bottom-up rather than the top-down. A 'truth', so The Clash's Joe Strummer would have it, known only to guttersnipes. ${ }^{7}$

\section{JOLT (1977): 'Well, why aren't there any real girl punk musicians around?'}

JOLT was put together by Lucy Whitman - writing as Lucy Toothpaste - in January 1977, one of the first wave of punk fanzines inspired by the example of Sniffin' Glue. It ran for three issues and conformed visually to a recognisable type: scrawled text enveloped by crudelycut newspaper clippings; photos and, later, drawings pasted at odd angles; a punk focus that 
doubled as personal commentary. Look closer, however, and JOLT carried an agenda beyond simply reporting back from gigs or the record shop. As Jon Savage noted in his fanzine round-up for Sounds in January 1978, JOLT was one of the few early 'zines to use the medium's lack of censorship to express a political position: to offer a critique; to engage with punk beyond mere celebration or cliché. ${ }^{8}$ More specifically, Whitman brought a feminist eye to punk, concentrating on the possibilities - and challenges - for 'girl bands' forming on the cusp of the new wave. 'I want to do lots of things on girl punks', she wrote in the first issue, 'specially who play the guitar'. JOLT was not 'just another punk mag': it was '(Just) Another punk mag for punks girls'. ${ }^{9}$

Whitman's introduction to punk came via a Sex Pistols' performance at Walthamstow's Assembly Hall in June 1976. Finding them 'intriguing' and 'exciting', she recognised in punk a 'space for anybody to do whatever they wanted'. ${ }^{10}$ For Whitman, then about to become a third-year English student at University College London, this meant both an opportunity for women to form bands and a chance to inject feminist ideas into rock ' $n$ ' roll. $J O L T$, therefore, was born with a particular modus operandi: to shape the politics of punk along suitably progressive lines. 'I brought my feminism with me into punk', Whitman recalled, having already played briefly in an all-female band called The Neons before joining Rock Against Racism (RAR) in 1977 and helping develop Rock Against Sexism (RAS) from $1978 .{ }^{11}$

Feminism and anti-fascism proved central to JOLT's style and content, paving the way for Whitman's later writing in RAR's Temporary Hoarding magazine, RAS' Drastic Measures bulletin and Spare Rib. The cover of JOLT's first issue featured Elli Medeiros from the French band Stinky Toys, with a newspaper strapline running diagonally across the page stating (not aimed towards Medeiros of course): 'How an ugly woman is transformed on 
stage into the beautiful queen of rock'. Smaller press clippings then peppered the 'zine's five pages, comprising brief snippets relating to Patti Smith and such fledgling all-girl bands as The Slits and The Castrators. ${ }^{12}$ Subsequent issues featured illustrated covers: JOLT number two was fronted by a punk Queen Elizabeth II celebrating her jubilee; issue three by the moral crusader Mary Whitehouse entwined in a lesbian embrace. Inside, photos of The Slits' Ari-Up (Arianne Foster), The Adverts' Gaye Black and X-Ray Spex's Poly Styrene (Marianne Elliot-Said) complemented typed-up interviews and essays. The contrast to the predominantly male faces staring out from most other punk fanzines was stark.

JOLT's first issue also presented a mission statement of sorts, urging girl bands to form, play and overcome any sense of doubt or self-consciousness. '[It] doesn't matter if we don't know how to play the guitar yet, we can soon learn to play as well as any other punk and I think the punk public is just waiting for more all-girl bands to appear'. For inspiration, Andy Warhol's would-be assassin Valerie Solanas was featured as a 'great punk [from] history', replete with extracts from her SCUM (Society for Cutting Up Men) manifesto. ${ }^{13}$ Thereafter, issues two and three built around pieces on The Slits and X-Ray Spex respectively, drawing together punk's female presence to show 'that girl punks have at last got going' ${ }^{14}$

Whitman's anti-fascism was not so predominant but clear nonetheless, finding expression in concern at punk's swastika-chic and susceptibility to right-wing influence. Issue three, published on the eve of the National Front's (NF) march through Lewisham on 13 August 1977, called for 'hordes of punks' to support a counter-demonstration and 'smash the idea that punk has anything to do with fascism once \& for all' ${ }^{15}$ In the event, the 'Battle of Lewisham' presaged the formation of the Anti-Nazi League and gave stimulus to RAR's efforts to mobilise punk support. ${ }^{16}$ 
The politics of JOLT reflected Whitman's own priorities. But she was not alone. For many young, not-so-young and proto- leftists, punk's oppositional spirit and approach complemented (and soundtracked) their own sense of revolt, with The Clash in particular seeming to provide a socially-conscious rock ' $n$ ' roll that was avowedly anti-racist. ${ }^{17}$ At the same time, Whitman's attempts to channel punk's politics revealed tensions resonant of the time. First, in relation to feminism, her interview with The Slits noted feminist antipathy to punk as but another variant of 'cock rock', to which Whitman argued that 'angry women should make an angry noise'. ${ }^{18}$ The pressures felt by women forming bands, especially the preconceptions of male reviewers, musicians and audience members, were relayed in both The Slits and X-Ray Spex articles. Yet Whitman's review of The Runaways and Sharon Dunham's review of a gig by The Slits (in issue two) each criticised, albeit from different angles, the bands for 'playing on' their femininity, as if the foregrounding of gender brokered a collision of critical theory, cultural expectation and subjective taste. ${ }^{19}$ Nevertheless, running through all three JOLTs were questions relating to such contemporary feminist debate as to whether all-female or mixed-gender groups served best to demonstrate women's cultural legitimacy; whether there was such a thing as 'male' and 'female' music; and how best to engage with and challenge the patriarchal structures of the music industry and everyday sexism.

Secondly, and similarly, the contested politics of punk's cultural assault were explored in an essay on 'Marxism \& the Mass Media', during which Whitman contemplated the folk-singer Leon Rosselson's assertion that rock was too much a product of the music industry to be a revolutionary force. Where Rosselson understood rock to emphasise a separation between glamorised performers and passive spectators, he claimed folk music and folk clubs by-passed the worst excesses of the industry and broke down the performer- 
audience divide. Again, the essay - based on a discussion held at the Film Co-op in Chalk Farm - was resonant of the time. ${ }^{20}$ Though too shy to join in the debate with those suggesting rock, not folk, was 'the music of the masses', Whitman's subsequent reflections fed into an analysis of punk's importance. Two observations stood out. Punk, as with all cultural forms, was full of contradictions, hence its containing 'tendencies towards both fascism and anarchism, which are polar opposites'. Like culture more generally, punk and rock ' $n$ ' roll were sites of struggle that had to be fought for. 'I think it's ridiculous to assume that one special type of music [...] is somehow untainted by ruling-class values', Whitman continued, noting that folk could be just as 'fucking sexist' and 'pretentious' as any other music. As importantly, she restated punk's progressive potential: that is, the enabling of assertive action via forming bands or writing fanzines; accessibility via cheap equipment and the rejection of virtuosity; a focus on everyday life rather than 'fantasies'; a popular appeal that meant those appropriated by 'big business' were soon replaced by other bands and other fanzines forming at the grass-roots. ${ }^{21}$

Third, and following on from the notion of punk as a contested culture, JOLT's antifascist content stemmed in part from a conversation Whitman had with a young punk at a party. He was wearing a swastika, but not for shock effect. He believed in repatriation, conscription and racial segregation. He was also singing along to The Clash's cover version of Junior Murvin's 'Police and Thieves', a reggae tune produced by Lee Perry in 1976 . For Whitman, whose description of the conversation in JOLT's third issue was surrounded by images of NF marches and pertinent newspaper clippings, this served, first and foremost, to prove fascism's irrationality. But it also reinforced her concern as to punk's susceptibility to reactionary influence. There followed a plea to 'fight back' and to 'get off the fence', with photos of Nazi atrocities serving as a reminder of where fascism leads. In such a context, 
Whitman's engagement with RAR and call for a punk presence to counter the NF in Lewisham marked her own solution. ${ }^{22}$ At the same time, her concern that anti-fascist violence was often counter-productive gave hint of differences within the left as to how best to confront the NF; differences that would rumble on into the 1980s whilst also informing punk-related cultures for which far-right interventions at gigs became a growing problem over the turn of the decade. ${ }^{23}$

Though lasting for just three issues, JOLT provided Whitman with a way into and a platform to engage with debates circulating on the left and feeding into popular culture. Having taken her feminism into punk, she then took her punk into feminism via RAS and contributions to Spare Rib. By so doing, Whitman contributed to a continuum that fed through RAR, RAS, Shocking Pink, riot grrrl and onto the burgeoning feminist punk scenes of the twenty-first century. ${ }^{24}$ Having used JOLT to access the political and cultural opportunities presented by punk, Whitman helped contest and shape the cultures that formed in the Sex Pistols' wake.

\section{Anathema (1982): 'People in Britain don't write like this'}

The Sex Pistols' 'Anarchy in the UK' (1976) ensured British punk came imbued with a political charge. Be it the 7-inch single wrapped in a sheer-black sleeve akin to the anarchist's flag or the promotional images of a ripped-up union jack held together by bullclips and safety-pins, the record looked, sounded and felt seditious. Whatever the meaning intended by Johnny Rotten's lyric, Jamie Reid's design or Vivienne Westwood and Malcolm McLaren's provocation, the injection of 'anarchy' into pop's lexicon - not to mention the furor surrounding the Sex Pistols' supposed violence and profanity - ensured debate as to 
the provenance of punk's politics. 'Anarchy', like 'fascism' and 'boredom', became a buzzword; the circled ' $A$ ' fed neatly into punk's semiotic arsenal. ${ }^{25}$

By 1980, punk's connection to notions of anarchy had begun to find deeper expression in bands such as Crass and Poison Girls. ${ }^{26}$ Though both groups formed in 1977, they remained relatively obscure prior to releasing their first records in early $1979 .{ }^{27}$ Both, too, committed to working wherever possible outside the mechanisms of the culture industry, recoiling from the appropriation of punk's first wave to adopt a resolutely autonomous position in the DIY spaces facilitated by the proliferation of independent labels and fanzines. Both included members with countercultural pasts that predated punk's emergence; both understood anarchy as more than simply a signal of subversion or a symbol of self-rule. Distinct from the binaries of 'left' and 'right', anarchy enabled Crass and Poison Girls to develop a libertarian politics that moved beyond the former's slogan of 'there is no authority but yourself'. ${ }^{28}$

The influence of Crass, in particular, is hard to overestimate. To flick through the independent charts of the early 1980s is to see Crass' records as almost ever-present, their output and performances spawning an array of bands, labels and acolytes inspired by their methods. ${ }^{29}$ Crass songs were often like treatises, with lyrics that unpicked, critiqued and attacked the structures of 'the system'. The sound was raw, giving caustic expression to ideas that were further complemented by Gee Vaucher's artwork on record sleeves that doubled as communiqués replete with essays, information and contacts. And though Crass eschewed the music press, their ideas were transmitted through an ever-growing number of interviews for fanzines that, in turn, began to replicate the aesthetic and deliberate on the politics of what eventually became known as anarcho-punk. 
Anathema was one such fanzine. Created by Lee Gibson, a nineteen-year-old from Longnewton (County Durham) attuned to punk following exposure to the Sex Pistols' 'God Save the Queen' in 1977, its two issues featured interviews with Crass, Poison Girls and the anarchist poet Andy $\mathrm{T}$ (Andrew Thorley) amidst an assortment of overtly-political essays and collages. Gibson had already produced 'zines prior to distributing Anathema in 1982, changing their titles regularly to avoid falling into a formula. In many ways, therefore, Anathema was a continuation of 1981's Protesting Children Minus The Bondage; indeed, Gibson's interview with Poison Girls traversed the two 'zines. Even so, taken as a pair, Anathema provides a pertinent example of how fanzines evolved to allow for formative political opinion to be worked out and communicated. Certainly, the ratio between music and politics tipped towards the latter with Anathema.

Gibson's discovery of Crass and Poison Girls brought focus to a critical sensibility already piqued by punk. Looking back, he described punk as a message: 'we were all ready and willing to challenge the status quo and the corrupt powers-that-be and to forge our own paths in life' ${ }^{30}$ But it was only after hearing, seeing, writing to, visiting and interviewing Crass and Poison Girls that Gibson's politics began to cohere. 'I stayed with Crass for a few days', he later recalled, 'half mesmerised; it was like a different world and made quite an impression on me. Crass were very organised and focused on what they were doing, whereas I was still making things up as I went along [...] It was the first time I actually glimpsed the possibilities of alternate ways of living. Something different from the usual family set up and all the restrictions that invariably come with that package' ${ }^{31}$ The results found expression, first, in interview form; then as essay, poem, short-story and collage.

The interviews with Crass and Poison Girls covered overlapping ground. ${ }^{32}$ While expected fanzine subjects - music, records, gigs - were touched upon, attention focused 
mainly on the politics developed in the bands' lyrics and lifestyles. Gibson engaged the bands in debate as to the meaning of anarchy; the dynamics and limits of organised protest; the complexities of class; the socially-defined constructs of 'family' and individual identity. 'There's always the thing of how do you see beyond [the system]', Crass' Penny Rimbaud (Jeremy Ratter) mused. 'I think it's very precious working with certain forms of behaviour and certain methods by which people can perceive beyond the definitions that they've been given'. ${ }^{33}$ In effect, Anathema became Gibson's means of doing just that.

In both issues, the structural foundations of state and society were dissected; their power relations exposed and decried. Attention was given to how distorted realities, forged by media, party-politics and religion, transferred to become the hegemonic values of everyday life. Collages juxtaposed newspaper headlines with images of violence; the gendered clichés of tabloid and TV were rendered ridiculous via saturation or recontextualisation. Essays about the 'clever con' of politics followed almost existential ruminations on the travails of existence and the historic implications of 'church control'. 'These are the lies I see being disguised. People's reliance on labour is based upon the agony or oppression of another human being. Company death. State death. The family feast on pain. $^{34}$

Ostensibly, the worldview espoused by Anathema - alongside such comparable 'zines as Acts of Defiance, Fack and Toxic Grafity - was bleak, a smorgasbord of violence, oppression and commercialised 'opiates' designed to distract from a life cast in the shadow of the cold war's impending nuclear apocalypse. Simultaneously, as Chris Low - producer of Guilty of What? fanzine and drummer for a series of anarchist bands - noted, the 'allencompassing ethos and ideology' of Crass et al provided a sense of 'identity and sovereignty'; an explanation and an outlet for the disaffection that stoked punk's ire. ${ }^{35}$ 
Anarchy thereby presented an 'alternative reality', a means of breaking down personal barriers of class, race, gender and sexuality towards what Gibson defined as a world of 'cooperations, not domination, not exploitation [...] peace not war. Love not hate. Constructive construction not destructive destruction. Care not violence. Intelligence not ignorance [...] We will work for real needs. For each other, not some smarmy boss [...] Not for commercial profit' ${ }^{36}$ And while such musings often rested on angsty platitudes that sometimes became as doctrinaire as those they opposed, the process of critical engagement rendered by writing an essay, poem or creating a collage at least served as a form of political rationalisation. The fanzine, moreover, provided the medium of expression; the means of communication.

Looking back, the anarchist 'zines produced in the early 1980s collated a remarkable historical record. They documented a reimaging of radical politics taking place on the margins of popular culture; revolutionary ideas bound to youth's obsession with music and style. Not only did they capture a process of adolescent questioning, they also revealed fumblings toward new politics and lifestyles distinct from the organisational and ideological mores of the twentieth century. For Gibson, punk combined with anarchist politics to open up new ways of thinking and doing. As well as providing a creative outlet, they paved the way for a life of squatting and intellectual enquiry. As the strapline to his autobiography puts it: 'I'm not sure what messed me up the most; Punk Rock, Anarchy, LSD, Magick or UFOs. I'm just thankful I got messed up.'37

\section{Hard As Nails (1983-85): 'Sussed Skins Against the Scum'}

Few cultures have been so reviled as skinhead. Emerging from the dissipation of mod in the later 1960s, skinheads embodied an avowedly working-class alternative to the hippie 
counter-culture resonant of the 'swinging sixties'. The style was all: boots, braces and button-down - sometimes collarless - shirts; jeans turned up or Levi sta-prest; cropped hair, short but never cut to the bone. Sheepskin coats were popular before crombies and harringtons eased the transition to suedehead; for a night out, mohair suits and brogues were complemented by a touch of Ivy League among the more discerning. ${ }^{38}$ Musically, the skinhead soundtrack comprised bluebeat, early reggae and soul, a mix that enabled Jamaican rude-boy influences to infuse the cross-cultural synergy. Equally, however, skinheads retained the territorial proclivities of their forebears, finding an outlet in football and local rivalries that enlivened a Saturday afternoon or night out. Though punch-ups and street-corner gangs were never the sole-preserve of skinheads, it was the 'bovver' that became the media's defining motif, especially if racial overtones could be teased from a story. A monster was born, captured for posterity in Richard Allen's popular novellas of the 1970s and made all too real by the far-right's cultivation of skinhead cadres later in the decade. ${ }^{39}$ By 1980 , 'skinhead' had become synonymous with 'neo-Nazi' in the public/media imagination; a racist yob, lumpen and violent.

There were different narratives, of course. Aspects of skinhead culture could vary across postcodes, let alone the UK. The media's codification of skinhead bore only tenuous relation to the experience of those described, although - as is often the way with youth subcultures - the clichéd caricature provided a template to copy and perpetuate. As a result, the politics of skinhead culture were always contested, be it in terms of 'left' and 'right' or the conventions of style. Moreover, by the time the NF and British Movement (BM) had begun to nurture young skins to their cause, so punk too had begun to inform the skinhead 'revival' that gathered around bands such as Sham 69. Both 2-Tone and Oi! emerged from the punk diaspora: the first an amalgam with ska that brokered cross-racial 
groups such as Specials, The Selecter and The Beat; the second a reassertion of punk as 'working-class protest' that included skinheads among its 'loose alliance' of 'tearaways, hooligans [and] rebels' ${ }^{40}$ The aesthetics, soundtrack and politics of being a skinhead were therefore in a state of uneasy flux by the turn of the decade; battlegrounds for those staking a claim to any 'true' skinhead identity.

Hard As Nails was very much a rejoinder to all this. Conceived by lan Hayes-Fry and Paul Barrett in 1983, two telecom and post office workers from Canvey Island, the 'zine was designed to become a 'focal point for sussed skins'; 'a reaction', as Hayes-Fry put it, 'to The Sun idea of skins'. Instead of 'scruffs' with 'bald heads, sniffing glue and birds in 18-hole Docs', Hard As Nails looked to affirm the 'real '69 skin-ideals' ${ }^{41}$ Attention to detail ensured Ben Sherman shirts, suits and brogues - Trevira skirts and penny-loafers for the girls eclipsed the MA-1 flying jackets, too-tight jeans and battered boots favoured by those mutating into far-right boneheads. Reggae, ska and soul came back to the fore, at least complementing Oi! and correcting what Barrett complained was punk's negative influence. 'Skinheads became just an extension of the punk shock thing with the bald heads and the tattoos on the forehead - [...] bald punks [...] a real moron element, people who think it's hard to be ignorant' ${ }^{42}$ As this suggests, Hard As Nails was an intervention: a means of reclaiming skinhead from the distortions of the media lens and, as importantly, the corrosive effect of punkish idiocy and far-right intrusion.

Ostensibly, the content of Hard As Nails was typical fanzine fare: band interviews, record lists and gig reviews. The first issue featured a piece on Oi!, picking out the good from the bad across the various compilation albums issued over 1980-83, and a jokey round-up of 'skinhead love songs'. ${ }^{43}$ But it also endeavored to reassert skinhead's cultural lineage, charting a history that marginalised the 'scummy' skins and 'plastic glueheads' in 
order to concentrate on those keen to 'stay sharp, stay sussed'. ${ }^{44}$ Running through the 'zines was the tale of 'arry 'arris, a cartoon version of a scruffy glue-sniffing skinhead sent back in time to meet his forebears in 1970. Given 'arry's facial tattoos, bald head, tatty jeans and jacket, the original skins mistake him for some kind of greaser and have no truck with his 'we're all white ain't we' politics. ${ }^{45}$

Much attention was given to skinhead's roots, with features on the early sounds and styles that defined the culture and interviews with 'originals' celebrating 'traditional [...] skinheadism'. ${ }^{46}$ So, for example, issue three traced the transition 'from skin to smooth', explaining the evolution of skinhead fashion over the early 1970s, while issue seven offered a guide to suitably sharp coats and jackets. ${ }^{47}$ Not dissimilarly, Hard As Nails emphasised the breadth of skinhead culture, eschewing political loyalties for class-cultural identity. As well as featuring 'scooter skins' and overviews of scenes across the UK and wider world, there were also essays on tattoos, boxing and the Kray Twins. Unusually for skinhead 'zines, too, space was given to skinhead girls, with 'renees' writing in to offset the male focus. The interview with Janice, 'an original skin-girl from South London', remains a rare insight. ${ }^{48}$

Of course, Hard As Nails could not expunge politics altogether. In issue two, the 'zines stance was bluntly stated: '[Skins] should be neither Nazi or Red. Skin is enough, the style and the music ... ${ }^{49}$ Where the far-right's politics were seen to be as shabby as their fashion sense, the far-left were regarded as middle-class trendies out-of-touch with the working class. Only Red Action - a grass-roots working class anti-fascist organisation received positive mention. Nevertheless, the political ramifications of such a position rumbled throughout all seven issues in some form or other. Features on avowedly socialist bands such as Burial, The Oppressed, Red London and The Redskins brought criticism from the 'proud to be white and proud to wear the union jack' brigade gathered in Islington's 
Agricultural pub, a hang-out for the far-right in the early 1980 s. $^{50}$ Simultaneously, editorial efforts to retain a distance between the fanzine and politics raised concern amongst those such as Shaz, a skinhead girl from Leeds, who felt 'the SWP and even Labour' were 'the only real way out'. 'The whole skin \& oi movement's supposed to be working class', she insisted, 'so when you have to get political, do make it clear where you stand.' ${ }^{11}$

Some punches were not pulled. Skrewdriver, an erstwhile punk band that adopted a skinhead image in 1977 and eventually came out openly for the NF in 1982, were given short shrift. 'What kind of skin would be seen dead with 3 days of stubble and a lumber jacket?' Politically, too, they were portrayed as chancers flirting 'with the sieg-heiling dickheads'. In short, Skrewdriver were the antithesis of everything Hard As Nails regarded as skinhead: Nazi-skins hiding swastikas behind union jacks; 'patriots (ha!) who chant kraut slogans and take their line from Italians'. '[Surely] people can see who the real enemy is? It's not the greasers, the punks, the mods. It's certainly not the blacks. We all know it's Maggie, her and everyone's bloody mindedness'. ${ }^{52}$

Images 3.1 \& 3.2 about here Hard as Nails, 3 and 4, both 1984 (Ian Hayes-Fry)

It would be ridiculous to suggest that Hard As Nails single-handedly redirected skinheads away from the politics and associated-aesthetics of the far-right. But it was important, nevertheless, in reasserting the culture's (pre-punk) history and presenting an alternative reading of skinhead's rationale. The 'zine helped connect and then reinforce links between 'sussed' skinhead milieus across the UK (including the Cardiff Skins, Glasgow's Spy-Kids, Southend's Clockwork Patrol); these, in turn, produced comparable 'zines (Backs Against the Wall, Bovver Boot, Crophead, Croptop, Spy-Kids, Street Feeling, Suedehead 
Times, Tell Us the Truth, Tighten Up, Zoot) that both challenged any overly London-centric perception of skinhead and further marginalised those coalescing around the Nazi-politics of the NF, BM, Skrewdriver and, ultimately, Blood \& Honour. ${ }^{53}$ Amongst references to keeping ideals and not losing sight of the past, Hard As Nails curated a class-cultural history: proud, stylish and sussed.

\section{Conclusion}

JOLT, Anathema and Hard As Nails offer three pertinent examples of processes evident across a fanzine culture given stimulus by punk. Beyond the sense of agency inherent in producing a 'zine, they offered opportunity to shape, collate and defend cultural practice in the face of media, commercial and, indeed, academic distortion. With JOLT, Lucy Whitman endeavored to apply a feminist and broadly-socialist reading to punk, critiquing aspects of the emergent culture whilst also denoting the progressive possibilities opened-up by notions of DIY. Whitman recognised punk - and culture generally - as a contested site that harboured contradictory tendencies and impulses. $J O L T$, therefore, provided a means of engagement, allowing Whitman to intervene in debate as to punk's political potential.

Anathema revealed more existential qualities, allowing Lee Gibson to reflect on, filter and apply the anarchist perspectives developed by Crass and Poison Girls to the world of which he was part. The result was an almost methodical deconstruction of the systems that maintained late-twentieth century society. In effect, Gibson offered articulate expression of his teenage angst, recognising the absurdities and abuses of life itself. Simultaneously, however, his writings - again inspired by the records he listened to and the bands he saw live - explored alternative lines of investigation: anarchism, political activism, even occultism. Looked at this way, his fanzine(s) enabled him to find a route out of the life 
he felt was mapped out before him through school, marriage, mortgage and work. 'I feel I ought to try and take a positive step in the right direction from poetry and antiestablishment scrawlings [...] YOU must change YOU [...] For the love of life ... LIVE!!'54

Finally, Hard As Nails offered reclamation of a subculture. Media distortions and farright incursions were seen to have faded the 'spirit of traditional, original' skinheads. In response, Hard As Nails provided opportunity to restate that original 'spirit' and critique those factors deemed to have caused degeneration. Class pride and the politics of style were reasserted in place of racism and tabloid caricature. A celebration of working-class culture was prioritised over the self-pity of those who wallowed in a 'scummy-gummy induced hell'. ${ }^{55}$

Each of these 'zines bore influence within the cultural milieus amongst which they circulated. Though all but hidden from the mainstream media's coverage of pop and youth culture, they nevertheless traced alternative narratives and dialogues resonant of their time. Modern cultural history is all too often defined - contained, even - by whatever was captured in newsprint or on celluloid. Meanwhile, on the ground, people made their own cultures and lived their own lives no less important than those transformed into spectacle.

\section{Notes}

Acknowledgments: My thanks to lan Hayes-Fry, Chris Low, Lucy Robinson, Toast (Dave Rumsey) and Tim Wells for comments, insights and material.

${ }^{1}$ Mark Perry, 'The Last Page', Sniffin' Glue, 1, 1976, p. 8; Mark Perry, Sniffin' Glue: The Essential Punk Accessory (London: Sanctuary, 2000). 
${ }^{2}$ Tony Drayton, 'My Excuse For This Self-Indulgent Escapade', Ripped \& Torn, 1, 1976, p. 3.

${ }^{3}$ Brass Tacks, Granada TV, 1977.

${ }^{4}$ Matthew Worley, 'Punk, Politics and British (fan)zines, 1976-84: "While the world was dying, did you wonder why?"', History Workshop Journal, 79 (2015), 76-106.

5 Teal Triggs, Fanzines (London: Thames \& Hudson, 2010); idem, 'Scissors and Glue: Punk Fanzines and the Creation of a DIY Aesthetic', Journal of Design History, 19:1 (2006), pp. 6983; Stephen Duncombe, Notes from the Underground: Zines and the Politics of Alternative Culture (Bloomington: Microcosm Publishing, 2008 edition).

${ }^{6}$ Brass Tacks, Granada TV, 1977. Other early Manchester fanzines included Ghast Up, Girl Trouble, Noisy People, Out There and Plaything. As should hardly need to be said, music fanzines - such as Hot Flash - existed in Manchester prior to punk's emergence.

${ }^{7}$ The Clash, 'Garageland', The Clash (CBS, 1977).

8 Jon Savage, 'Pure Pop Art for Now People', Sounds, 14 January 1978, pp. 17-18.

9 JOLT, 1 (1977), pp. 2-4.

${ }^{10}$ Quoted in Cazz Blase, 'A Woman Called Toothpaste: An Interview with Lucy Whitman', The f-word, 20 May 2011.

11 Blase, 'A Woman Called Toothpaste' (unpaginated); Martha Zenfell, 'Love Sex, Hate Sexism?', NME, 7 April 1979, p. 15; Daniel Rachel, Walls Come Tumbling Down: The Music and Politics of Rock Against Racism, 2-Tone and Red Wedge (London: Picador, 2016); lan Goodyer, Crisis Music: The Cultural Politics of Rock Against Racism (Manchester University Press, 2009).

12 The Castrators were a short-lived band that included Tessa Pollitt, later of The Slits. The snippets used in Jolt included bits from Carolyn Martin, 'Here Come the Punkesses', News of 
the World, 16 January 1977, p. 3 and Caroline Coon's Melody Maker guide to punk, 27 November 1976, pp. 33-9.

${ }^{13}$ Solanas quotes also decorated the walls of SEX, the shop run by Vivienne Westwood and Malcolm McLaren that cultivated punk's early attitude and aesthetic.

14 'Editorial', JOLT, 2 (1977), p. 4.

15 'Just Another ...', JOLT, 1 (1977), p. 4; 'Important Message' and 'Off Your Rocker', JOLT, 3 (1977), pp. 6-8.

${ }^{16}$ Dave Renton, When We Touched the Sky: The Anti-Nazi League, 1977-81 (Cheltenham: New Clarion Press, 2006).

17 Matthew Worley, 'Shot By Both Sides: Punk, Politics and the End of "Consensus"', Contemporary British History, 26:3 (2012), 333-54.

18 'The Slits', JOLT, 2 (1977), p. 2.

19 'Girl Bands', JOLT, 1 (1977), p. 3; Sharon Dunham, 'Review', Jolt, 2 (1977), pp. 3-4.

20 Matthew Worley, 'Marx-Lenin-Rotten-Strummer: British Marxism and Youth Culture in the 1970s', Contemporary British History, 30/4 (2016), 505-21.

21 'Music and the Mass Media', JOLT, 2 (1977), p. 5.

22 'Off Your Rocker', JOLT, 3 (1977), pp. 7-8.

${ }^{23}$ Sean Birchall, Beating the Fascists: The Untold Story of Anti-Fascist Action (London: Freedom Press, 2010); Kill Your Pet Puppy, 1 (1980); Worley, 'Shot By Both Sides', 333-54.

${ }^{24}$ Lucy Whitman, 'Women and Popular Music', Spare Rib, June 1981, pp. 6-8 and pp. 20-1; Julia Downes, 'Riot Grrrl: The Legacy and Contemporary Landscape of DIY Feminist Cultural Activism', in Nadine Monem (ed.), Riot Grrrl: Revolution Girl Style Now! (London: Black Dog Publishing, 2007), pp. 12-49; Anna Gough-Yates, “'A Shock to the System": Feminist 
Interventions in Youth Culture - The Adventures of Shocking Pink', Contemporary British History, 26:3 (2012), 375-403; Kevin Dunn and May Summer Farnsworth, "'We are the Revolution": Riot Grrrl Press, Girl Empowerment and DIY Self-publishing', Women's Studies 41:2 (2012), 136-57; Laura Cofield and Lucy Robinson, "The Opposite of the Band": Fangrrrling, Feminism and Sexual Dissidence', Textual Practice, 30:6 (2016), 1071-88.

${ }^{25}$ The nod here to Alternative TV's 'How Much Longer' (1977) is obviously deliberate.

${ }^{26}$ For a discussion of punk's relationship to anarchy see Russ Bestley, 'Big A Little A: The Graphic Language of Anarchy', in Mike Dines and Matthew Worley (eds) The Aesthetic of Our Anger: Anarcho-punk, Politics and Music (Colchester: Minor Composition, 2016), pp. $43-66$.

${ }^{27}$ Crass' debut EP, The Feeding of the Five Thousand, was scheduled to be released in late 1978 but was delayed until 1979 following a dispute at the pressing plant. Objection was taken to the blasphemous content of 'Asylum', the EP's opening track.

${ }^{28}$ Richard Cross, 'The Hippies Now Wear Black: Crass and the Anarcho-Punk Movement, 1977-84', Socialist History, 26 (2004), 25-44; idem, “"Take the Toys from the Boys": Gender, Generation and the Anarchist Intent in the Work of Poison Girls', Punk \& Post-Punk, 3:2 (2015), 117-45.

${ }^{29}$ Ian Glasper, The Day the Country Died: A History of Anarcho Punk, 1980-1984 (London: Cherry Red, 2006).

30 'I heard [Sex Pistols' 'God save the Queen'] and bang [...] I fell in love with this new angry music [...] the rejects of society were beginning to unite'. Lee G. [Gibson], A Punk Rock Flashback (London: Lulu Press, 2013), pp. 13-18.

${ }^{31}$ G., A Punk Rock Flashback, p. 45. 
32 'Poison Girls Interview', Protesting Children Minus The Bondage, 2 (1981), pp. 10-12; 'Poison Girls', Anathema, 1 (1982), pp. 31-2; 'Crass Interview', Anathema, 1 (1982), pp. 1114.

33 'Crass Interview', p. 14.

34 'The Art of Politics/A Clever Con', Anathema, 1 (1982), p. 28; 'Life Today', Anathema, 1 (1982), p. 17' 'Church Control', Anathema, 1 (1982), p. 19; 'Company Dreams', Anathema, 2 (1982), p. 23.

${ }^{35}$ Chris Low interview with Russ Bestley (August 2014), quoted in Bestley, 'Big A Little A', pp. $53-4$.

36 'Revolution The Pipe Dream', Anathema, 2 (1982), p. 32.

${ }^{37}$ G., A Punk Rock Flashback, cover.

38 'Jim Ferguson's Fashion Notebook', in Nick Knight, Skinhead (London: Omnibus Press, 1982), pp. 36-47

39 Bill Osgerby, "Bovver" Books of the 1970s: Subcultures, Crisis and "Youth-Sploitation" Novels', Contemporary British History, $26: 3$ (2012), 299-331; Matthew Worley and Nigel Copsey, 'White Youth: The Far Right, Punk and British Youth Culture', Journalism, Media and Cultural Studies, 9 (2016), pp. 27-47.

${ }^{40}$ Rachel, Walls Come Tumbling Down, 231-336; Dave Thompson, Wheels out of Gear: 2Tone, The Specials and a World in Flame (London: Helter Skelter, 2004); sleevenotes to Various Artists, Oi! The Album (EMI, 1980); Garry Bushell, 'The New Breed', Sounds, 1 November 1980, pp. 32-3; 'Oi! - The Column', Sounds, 17 January 1981, 11. For pre-2-Tone reference to multi-racial skinhead gangs, see Garry Bushell's coverage of the second ANL carnival in Sounds, 30 September 1978, p. 46. 
${ }^{41}$ Quoted in Garry Bushell, 'Burial Plot', Sounds, 10 November 1984, p. 20.

42 Ibid.

${ }^{43}$ I have been unable to locate a copy of the first Hard As Nails, so my thanks to lan HayesFry for providing me with an overview of issue 1

${ }^{44}$ Editorial to Hard As Nails, 3 (1984), p. 2.

45 There is a nod here, in 'arry's comment, to 'Chubby' Chris Henderson's appearance on the BBC documentary 'Skinheads' (1982), part of the Arena series. Henderson was the lead singer with Combat 84 and British Movement stalwart. Closer to home, Hayes-Fry also recalled: 'a bunch of BM skins had come down from Basildon to The Grand Hotel in Leighon-(pre-gentrification)-Sea to trash a gig, and that confused "but we're all white" line came when their ringleader grabbed a mic and pathetically attempted to justify himself and misguidedly appeal for some sort of racial solidarity from a pissed-off and/or completely bemused audience' [correspondence with author, 7 December 2016].

46 'H.A.N.', Hard As Nails, 2 (1984), p. 2; 'Skinhead Remembrance', Hard As Nails, 7 (1985), pp. 10-11.

47 'From Skin to Smooth: The End of a Style', Hard As Nails, 3, (1984), p. 14.

48 'Class of '69', Hard As Nails, 5 (1985), pp. 8-9.

49 The quote is from Hard As Nails, 2 (1984), p. 14.

${ }^{50}$ Letter from Andy, Paul et al, Hard As Nails, 5 (1985), p. 18.

${ }^{51}$ Letter from Shaz, Hard As Nails, 2 (1984), p. 14. See also Gaz from Darlington's letter in issue 3.

52 'Redskins', Hard As Nails, 3 (1984), pp. 8-9. 
${ }^{53}$ Due mention should be given to Boots \& Braces, Chargesheet and Skins as skin-zines that tried to avoid politics and pre-dated Hard As Nails. All, however, were (initially) somewhat ambivalent to the scene that eventually coalesced around Skrewdriver.

54 'Revolution The Pipe Dream', Anathema, 2 (1982), p. 32.

55 'On the Deck', Hard As Nails, 7 (1985), p. 15. 